\title{
INTERMITTENT POSITIVE PRESSURE RESPIRATION AS A TREATMENT IN SEVERE RESPIRATORY DISTRESS SYNDROME*
}

\author{
BY \\ M. DELIVORIA-PAPADOPOULOS, H. LEVISON, and P. R. SWYER \\ From the Research Institute of the Hospital for Sick Children, and the Department of Paediatrics, \\ University of Toronto
}

(RECEIVED FOR PUBLICATION NOVEMBER 30, 1964)

Since the initial work of Donald and Lord (1953) and Donald, Kerr, and MacDonald (1958), there have been several reported survivals of infants with the respiratory distress syndrome (RDS) treated by assisted ventilation (Benson, Celander, Haglund, Nilsson, Paulsen, and Renck, 1958; Stahlman, Young, and Payne, 1962; Delivoria-Papadopoulos and Swyer, 1963; Heese, Wittmann, and Malan, 1963). Previous work in our unit (Delivoria-Papadopoulos and Swyer, 1964) demonstrated the possibility of reversing at least temporarily the biochemical changes of terminal asphyxia in patients dying with RDS.

The purpose of this study was to gain further information regarding criteria for initiating assisted ventilation and its technique in relation to the clinical features and course of the disease.

\section{Material and Methods}

The diagnosis of RDS in the 20 infants in this study was based on the usually accepted clinical (Dunham, 1961) and radiological (Peterson and Pendleton, 1955) criteria.

Previous experience of assisting ventilation, begun only

* Supported in part by a grant from the Department of National Health and Welfare, Ottawa, Canada, and in part by a grant-in-aid from the Banting Research Foundation. after repeated resuscitative attempts by bagging had failed, yielded only 1 survivor out of 19 (DelivoriaPapadopoulos and Swyer, 1964). In our present series assisted ventilation was started as soon as it was obvious that mask bagging would be ineffective in restoring sustained respiration. Thus infants did not deteriorate over many hours as in our previous series. Even so, 8 were in cardiac arrest and 16 were severely bradycardic $(<60 / \mathrm{min}$.). All had the biochemical picture of profound hypoxaemia and hypoventilation when first intubated and ventilated. Their clinical and biochemical data are summarized in Table 1. The gestational ages, birth weights, and clinical details are given in Table 2 . The infants were intubated with Cole's endotracheal tubes, No. 10-16 according to the baby's size, and intermittent positive pressure respiration (IPPR) was given with the Bird Mark VIII ventilator equipped with the minimal dead space (0.28 ml.) infant circle (S. Segal, 1963, personal communication). Pressures used in severely ill infants were of the order of $30-35 \mathrm{~cm} . \mathrm{H}_{2} \mathrm{O}$. With improvement in the clinical and biochemical condition, pressures could be gradually reduced to $15-18 \mathrm{~cm}$. $\mathrm{H}_{2} \mathrm{O}$. It was necessary also to increase pressures temporarily after airway suction. Respiratory rates were maintained between 50 and $70 / \mathrm{min}$., using automatic triggering if the infant did not spontaneously breathe at these rates. Regulation within these ranges was made by clinical judgement of the degree of expansion of the infant's chest, the infant's colour, activity, and response to stimuli. The ' $40 \%$ air mix' on the ventilator was selected, though it is likely that oxygen percentages

TABLE 1

CLINICAL AND BIOCHEMICAL STATUS OF INFANTS AT THE START OF IPPR

\begin{tabular}{|c|c|c|c|c|c|c|}
\hline \multicolumn{3}{|c|}{ Clinical Signs } & \multicolumn{3}{|c|}{ Acid-Base Balance } & \multirow{2}{*}{$\begin{array}{c}\mathrm{PaO}_{2} \text { in } 100 \% \\
\mathrm{O}_{2}\end{array}$} \\
\hline Respiration & Heart & Colour & $p \mathbf{H}$ & $\mathrm{PaCO}_{2}$ & B.B. $(p)^{*}$ & \\
\hline $\begin{array}{l}\text { Arrest, }< \\
\text { 3/min., or } \\
\text { gasping }\end{array}$ & $\begin{array}{l}\text { Arrest or } \\
<60 / \text { min. }\end{array}$ & $\begin{array}{l}\text { Central + } \\
\text { peripheral } \\
\text { cyanosis in } \\
100 \% \mathrm{O}_{2}\end{array}$ & $<6.80$ & $>120 \mathrm{~mm} . \mathrm{Hg}$ & $<25 \mathrm{mEq} / \mathrm{l}$. & $<30 \mathrm{~mm} . \mathrm{Hg}$ \\
\hline
\end{tabular}


TABLE 2

CLINICAL DETAILS OF TWENTY INFANTS WITH RESPIRATORY FAILURE TREATED WITH IPPR

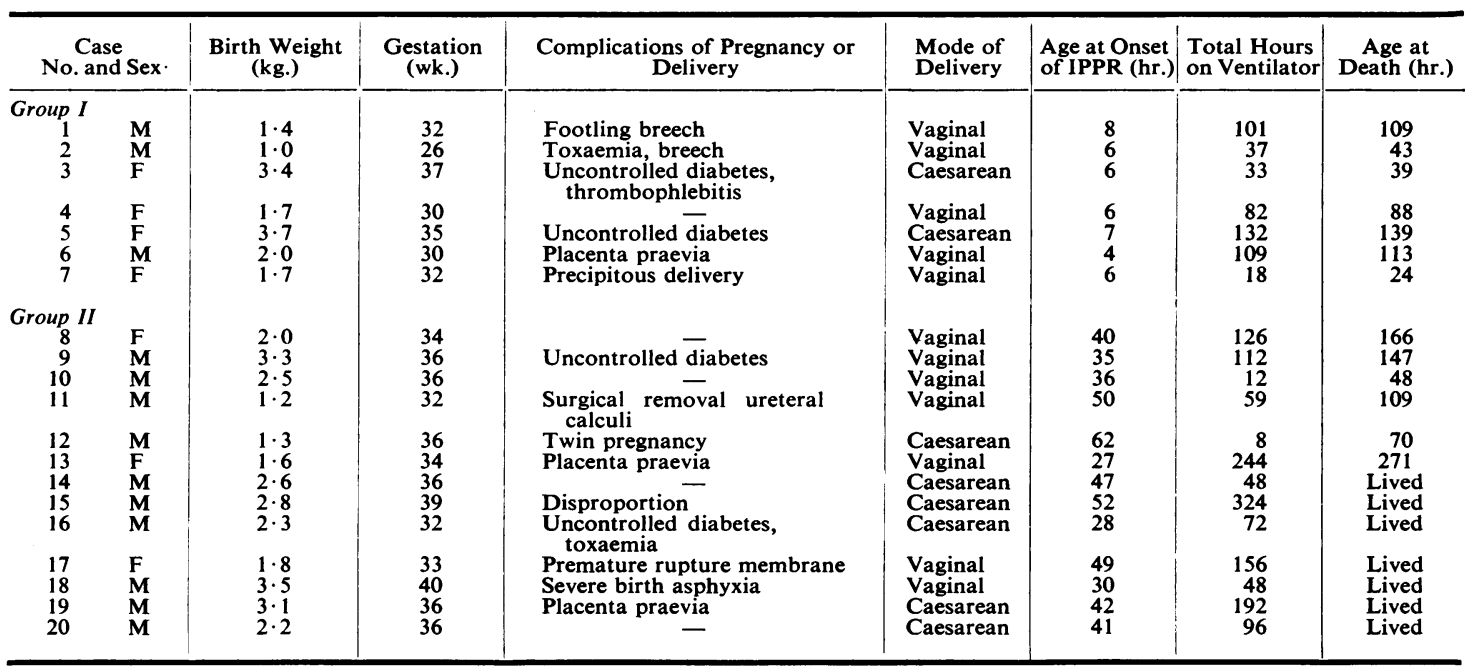

averaging 60 or more resulted (Fairley and Britt, 1964). The adequacy of alveolar ventilation so obtained was checked by periodic $\mathrm{PaCO}_{2}$ measurements (Figs. 2 and 3). Following intubation and initiation of IPPR, a low tracheostomy was performed (Fearon, 1962; Fearon, Smith, Delivoria-Papadopoulos, Levison, and Swyer, 1964) within 12 hours to facilitate the maintenance of a clear airway. All infants had serial arterial blood gas and chemical studies after admission, immediately before and after IPPR, and at 3- to 6-hour intervals for the first two days, then at 8- to 12-hour intervals. After the 6th day on the ventilator, blood acid-base determinations were done daily. In 14 infants the umbilical artery was catheterized with a No. 5 French polyvinyl tube filled with heparinized saline. On removal of the catheters blood was sampled by femoral artery puncture. All infants received $10 \%$ glucose intravenously $(65 \mathrm{ml} . / \mathrm{kg}$./ day) and sodium bicarbonate by slow syringe injection according to the estimated base deficit. Blood transfusion was given (in 11 infants) in the presence of a haematocrit below $38 \%$. Electrocardiogram, heart rate, respiratory rate, and colonic and environmental temperatures were monitored. Blood $p \mathrm{H}$ was measured by glass electrode (Astrup, Jørgensen, Siggaard Anderson, and Engel, 1960), $\mathrm{CO}_{2}$ content by means of KoppNatelson gasometer (Natelson, 1951), $\mathrm{PCO}_{2}$ by the Severinghaus electrode (Severinghaus and Bradley, 1958), and $\mathrm{PO}_{2}$ by the Clark electrode (Severinghaus and Bradley, 1958) after a 15-minute period of breathing $100 \% \mathrm{O}_{2}$ on the ventilator. Plasma buffer base was derived from the Singer-Hastings nomogram (Singer and Hastings, 1948). All measurements were made at $38^{\circ} \mathrm{C}$., and no correction was made for the infant's body temperature.

\section{Results}

The infants were divided into two groups according to the duration of the clinical course from birth to cardio-respiratory failure. Group I (7 infants) had a short clinical course before failure (4-8 hours). The mean age at failure and start of IPPR was 7 hours (Fig. 1 and Table 2). Death occurred after an average of 72 hours on the ventilator. Necropsy revealed hyaline membrane disease (HMD) in every case.

Group II (13 infants) had a longer clinical course (28-52 hours) from birth to respiratory failure. The mean age at acute decompensation and start of IPPR was $\mathbf{4 0}$ hours. The mean ventilator time was 132 hours (Fig. 1 and Table 2). Of the 13 infants, 6 died; necropsy revealed HMD in all. Complications are summarized in Table 3. Klebsiella pneumonia was treated with Cephalosporin C. While all fatal cases had post-mortem evidence of HMD, additional intractable infection and technical problems associated with airway maintenance were the final cause of death in 6 patients in Group II. The technical aspects of IPPR and tracheostomy have been discussed in another communication (Fearon et al., 1964). Seven infants were weaned off the ventilator and with one exception were apparently mentally and physically normal at 22,18 , $14,13,10$, and 7 months of age, though more prolonged follow-up is being carried out. One infant (Case 18) is retarded but had a traumatic delivery. 


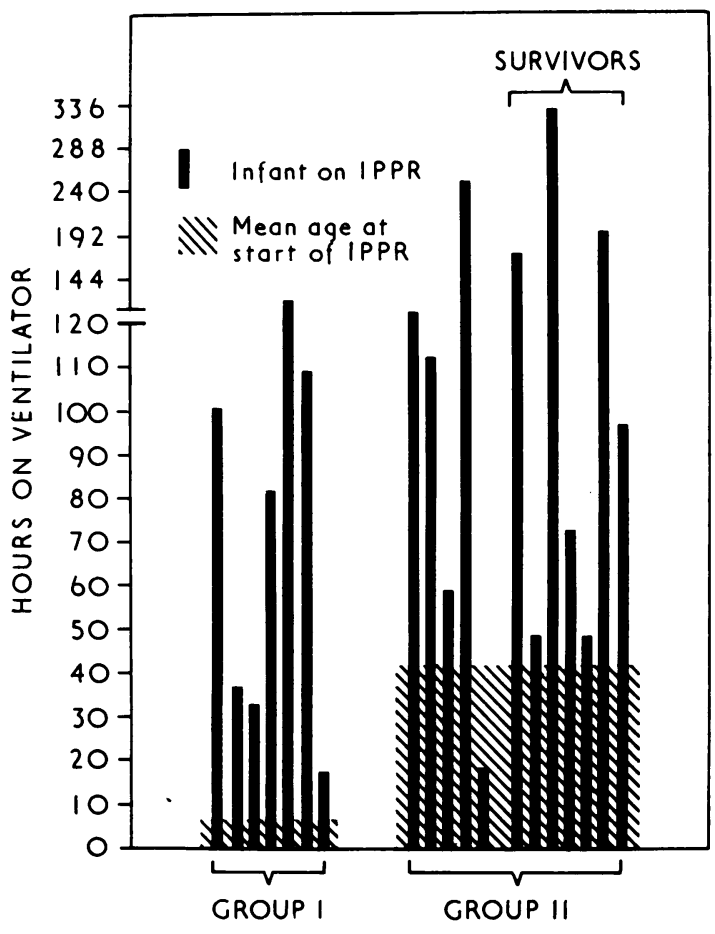

FIG. 1.-Duration of positive pressure ventilation in Group I (initiated at a mean age of 7 hours) compared with Group II (initiated at a mean age of 40 hours).

It is of interest that 2 of the 7 survivors had cardiac arrest which yielded to external cardiac massage combined with the assisted ventilation.

Representative examples of the biochemical course for Groups I and II are given in Figs. 2 and 3.*

* A Table giving serial biochemical data for each patient will be forwarded on request by one of the authors (P.R.S.).

\section{Discussion}

There was a clear difference between the two groups clinically and biochemically. In Group I, where the short clinical course from birth to cardiorespiratory failure indicated a more severe disease, IPPR applied at the onset of acute decompensation improved the condition only temporarily. Though the respiratory and metabolic acidoses were both corrected within 6 hours, subsequent deterioration set in after a variable interval from 24 to 139 hours (Fig. 2).

The infants in Group II seemed at first to be as severely ill as those in Group I judging by the physical examination, retraction score, radiographs, and biochemical status. However, they were able to maintain reasonable compensation for the degree of hypoventilation and kept their acid-base balance within limits compatible with life for at least 24 hours by maximal muscular respiratory effort, though additional bicarbonate buffer was given as required to repair deficits (Case 19, Fig. 3). The immediate cause of their failure before IPPR was begun seemed to be neuromuscular exhaustion rather than overwhelming lung disease.

Compared to Group I, the infants of Group II improved much faster on IPPR. Respiratory acidosis was restored to normal within the first hour and the metabolic acidosis treated with buffers was maintained within normal limits throughout the course of IPPR.

The $\mathrm{PaO}_{2}$ levels in Group I, while breathing $100 \%$ oxygen, showed an early but poorly maintained improvement and by 36 hours were falling once more. In contrast, Group II patients showed a steady improvement in $\mathrm{PaO}_{2}$ to reach normal levels by the fourth day on the ventilator (Fig. 4), indicating a reduction in the large A-a gradient characteristic of the acute stage of the disease (Nelson, Prod'hom, Cherry, Lipsitz, and Smith, 1963; Strang and

TABLE 3

MEDICAL AND TECHNICAL COMPLICATIONS IN TWENTY INFANTS TREATED WITH IPPR

\begin{tabular}{|c|c|c|c|c|c|c|c|}
\hline \multicolumn{4}{|c|}{ Complications in 13 Fatal Cases } & \multicolumn{4}{|c|}{ Complications in 7 Survivors } \\
\hline Technical & $\begin{array}{l}\text { No. of } \\
\text { Infants }\end{array}$ & Medical & $\begin{array}{l}\text { No. of } \\
\text { Infants }\end{array}$ & Technical & $\begin{array}{l}\text { No. of } \\
\text { Infants }\end{array}$ & Medical & $\begin{array}{l}\text { No. of } \\
\text { Infants }\end{array}$ \\
\hline $\begin{array}{l}\text { Tube in right main } \\
\text { bronchus }\end{array}$ & 12 & $\begin{array}{l}\text { Klebsiella } \\
\text { pneumonia }\end{array}$ & 7 & $\begin{array}{l}\text { Tube in right } \\
\text { main bronchus }\end{array}$ & 6 & $\begin{array}{l}\text { Klebsiella } \\
\text { pneumonia }\end{array}$ & 4 \\
\hline Tube in left main & 3 & $\begin{array}{l}\text { Erythroblastosis } \\
\text { foetalis }\end{array}$ & 2 & Tube in left main & 1 & $\begin{array}{l}\text { Unknown } \\
\text { pneumonia }\end{array}$ & 1 \\
\hline $\begin{array}{c}\text { Subcutaneous tube } \\
\text { displacement }\end{array}$ & 4 & Intracerebral & 3 & $\begin{array}{l}\text { Obstructive } \\
\text { secretions }\end{array}$ & 7 & Pneumothorax & 1 \\
\hline $\begin{array}{l}\text { Leak past tracheos- } \\
\text { tomy tube }\end{array}$ & 6 & disease of & 1 & $\begin{array}{l}\text { Subcutaneous } \\
\text { tube displace- }\end{array}$ & 3 & Anaemia & 5 \\
\hline Obstructive secretions & 13 & $\begin{array}{l}\text { newborn } \\
\text { Pneumothorax }\end{array}$ & 3 & $\begin{array}{l}\text { Leak past trach- } \\
\text { eostomy tube }\end{array}$ & 7 & $\begin{array}{l}\text { Hyperbilirubin- } \\
\text { aemia }\end{array}$ & 1 \\
\hline
\end{tabular}




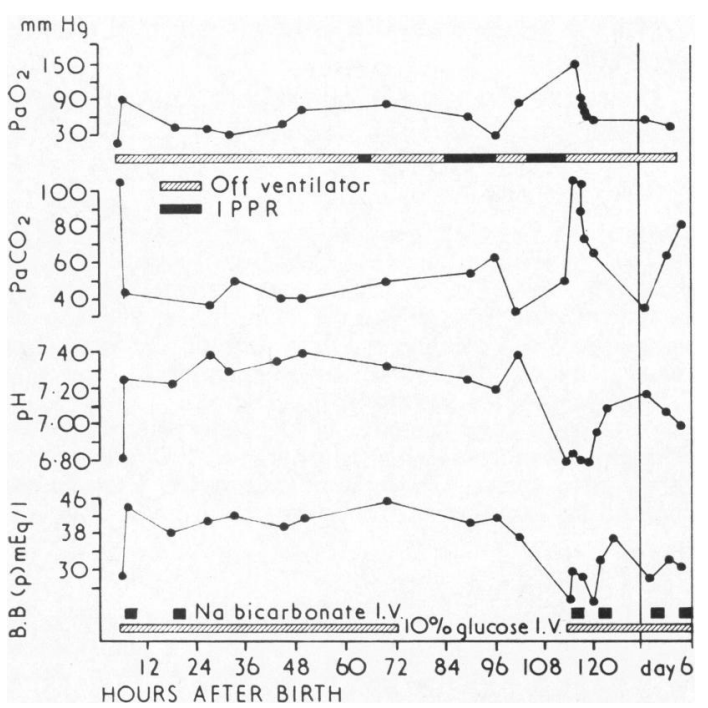

Fig, 2-Biochemical course of infant (Case 5, Group I) from the start of intermittent positive pressure respiration at 7 hours of age until death on day 6. B.B.(p) = plasma buffer base.

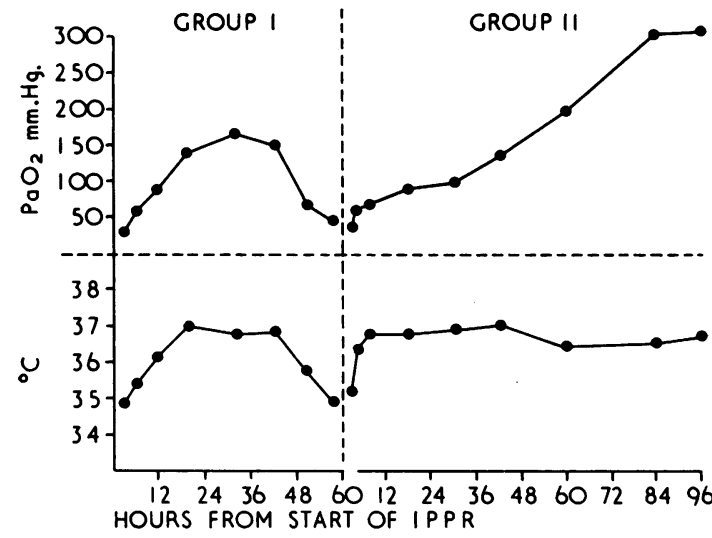

FIG. 4.-Mean arterial oxygen tensions after breathing $100 \%$ oxygen for 15 minutes, and colonic temperatures of 4 infants in Group I and 8 infants in Group II during positive pressure ventilation.

MacLeish, 1961; Warley and Gairdner, 1962). The effects of continued exposure to the relatively high oxygen percentages delivered by the ventilator (even with the ' $40 \%$ air mix') are unknown but may be harmful (Robertson, Tunell, and Rudhe, 1964). Improvements in ventilator design permitting graded reduction in oxygen concentrations are desirable.

Since in Group I the mean time on the respirator was relatively short ( 72 hours, Fig. 1, Table 2 ), the technical and medical complications associated with

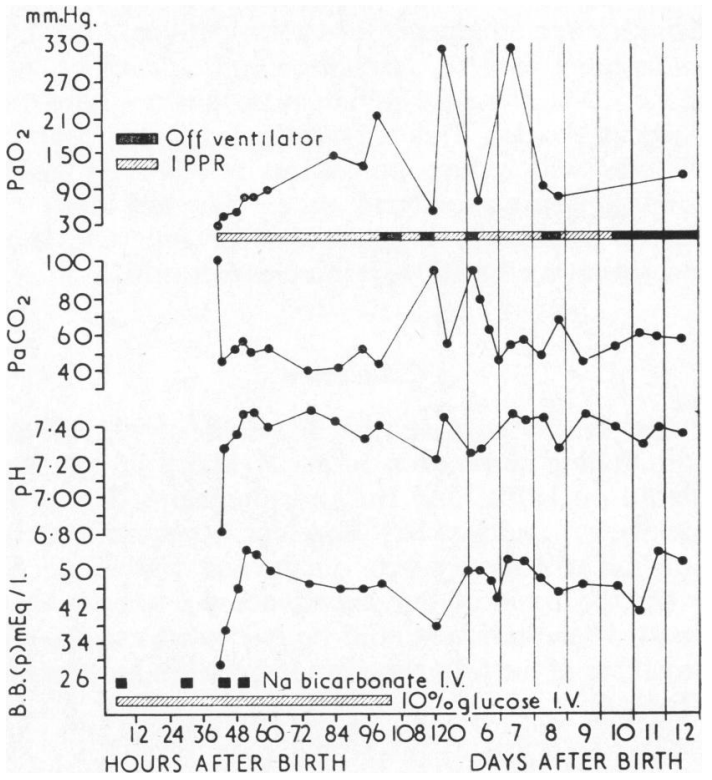

Fig. 3.-Biochemical course of infant (Case 19, Group II) from the start of intermittent positive pressure respiration at 42 hours of age (lived).

IPPR were not as prevalent as with the infants of Group II who required ventilation for longer periods (up to 14 days).

Our results suggest that when respiratory failure occurs after, rather than before, 24 hours of age, there is a better chance of survival with assisted ventilation. The patients who suffer respiratory failure within the first $\mathbf{2 4}$ hours after birth (Group I) have probably severe progressive pulmonary disease, and IPPR merely prolongs, rather than saves, life.

In Group II, it seemed that there was minimal progression of pulmonary changes, thus permitting survival by applying IPPR 'as an extra respiratory muscle' which alleviated neuromuscular exhaustion, and thus allowed a relatively normal acid-base balance to be maintained and possibly prevented further pulmonary collapse.

No infant weighing less than $1,800 \mathrm{~g}$. at birth survived in either group.

It is pertinent here to make some general remarks on the management of ventilators in the treatment of respiratory failure in such cases. According to Didier and Helmholz (1964) the problems with infants 'seem to increase exponentially as patient size diminishes'. This is certainly our own experience and any success with this method is completely dependent on continuous well-trained, experienced nursing and medical supervision, with 24-hour 
facilities for biochemical determinations. Infants undergoing assisted ventilation must never be left alone. Maintenance of adequate airflow into the lungs is crucial, and a breakdown of less than 5 minutes will reduce an infant in relatively good condition to a moribund state. For any hope of success a suitable organization for intensive care incorporating the above principles is essential.

\section{Conclusion}

Our results suggest that if infants over $1,800 \mathrm{~g}$. with failing respiration after 24 hours of age are placed on IPPR, and before a damaging degree of metabolic acidosis has developed, approximately one-half will survive with our present methods.

On the basis of our experience we suggest that assisted ventilation should be instituted as soon as any three of the following five indications are present (Table 4).

TABLE 4

INDICATIONS FOR ASSISTED VENTILATION

\begin{tabular}{c|c|c|c|c}
\hline \multicolumn{2}{c|}{ Clinical } & \multicolumn{2}{c|}{ Biochemical } \\
\cline { 1 - 4 } $\begin{array}{c}\text { Respiratory } \\
\text { Rate }\end{array}$ & Heart Rate & Colour & $\mathrm{PaCO}_{2}$ & $\mathrm{PaO}_{2}$ \\
\hline $\begin{array}{c}<30 / \mathrm{min} . \\
\text { or } \\
>120 / \mathrm{min} .\end{array}$ & $\begin{array}{c}<80 / \mathrm{min} . \\
\text { or }\end{array}$ & $\begin{array}{c}\text { Generalized } \\
\text { cyanosis } \\
\text { in } 100 \% \\
\mathrm{O}_{2}\end{array}$ & $\begin{array}{c}>80 \mathrm{~mm} . \\
\mathbf{H g}\end{array}$ & $\begin{array}{c}<40 \mathrm{~mm} . \\
\mathbf{H g} \text { while } \\
\text { breathing } \\
100 \% \mathrm{O}_{2}\end{array}$ \\
\hline
\end{tabular}

If further work confirms our results, a decrease in mortality in infants over $1,800 \mathrm{~g}$. could be anticipated. While approximately $40 \%$ of our mortality from RDS in this exclusively referral hospital takes place in infants weighing over $1,800 \mathrm{~g}$. at birth (Hanley, Braudo, and Swyer, 1963), it is probable that this represents only about $5 \%$ of the over-all mortality from RDS in the population at large. Thus we suggest that assisted ventilation should only be considered in centres where special facilities can be concentrated.

\section{Summary}

Twenty infants dying from acute cardiorespiratory failure due to respiratory distress syndrome were ventilated by intermittent positive pressure respiration.

Of these 20,7 died at less than 24 hours of age and IPPR merely prolonged life; 13 died at more than 24 hours of age; and 7 survived, 6 as yet having no evidence of neurological damage.
Criteria are suggested for the selection of patients for IPPR.

The needs of an organization carrying out assisted ventilation in infants are discussed.

We thank Dr. C. E. Snelling and other members of the staff of the Hospital for Sick Children for their help and encouragement, Dr. B. Fearon for surgical advice and for performing tracheostomies, Dr. S. H. Jackson for biochemical advice, the nursing staff of the premature nursery, Mr. D. McIntosh for technical help, and Miss C. MacLennan for secretarial assistance.

We acknowledge the help of Dr. Peter Fleming in the management of Klebsiella pneumonia with Cephalosporin C; we also thank Glaxo Laboratories of Canada and England for supplies of Cephalosporin C.

\section{REFERENCES}

Astrup, P., Jørgensen, K., Siggaard Anderson, O., and Engel, K. (1960). The acid-base metabolism: A new approach. Lancet, $1,1035$.

Benson, F., Celander, O., Haglund, G., Nilsson, L., Paulsen, L., and Renck, L. (1958). Positive-pressure respirator treatment of severe pulmonary insufficiency in the newborn infant. A clinical report. Acta anaesth. scand., $2,37$.

Delivoria-Papadopoulos, M., and Swyer, P. R. (1963). An experimental study of the possibility of reversing the biochemical changes of terminal hyaline membrane disease by assisted ventilation. Program and abstracts. Soc. for Pediatric Research, 33rd Annual Meeting, p. 33. (Abstr. J. Pediat., 63, 733.)

, (1964). Assisted ventilation in terminal hyaline membrane disease. Arch. Dis. Childh., 39, 481.

Didier, E. P., and Helmholz, H. F., Jr. (1964). Principles in the selection and use of mechanical ventilators and assisters. Med. Clin. N. Amer., 48, 867.

Donald, I., Kerr, M. M., and MacDonald, I. R. (1958). Respiratory phenomena in the newborn. Experiments in their measurement and assistance. Scot. med. J., 3, 151.

_ atelectasis neonatorum. Lancet, $1,9$.

Dunham, E. C. (1961). Premature Infants, 3rd ed., ed. W. M. Silverman, pp. 231-235. Hoeber, New York.

Fairley, H. B., and Britt, B. A. (1964). The adequacy of the air-mix control in ventilators operated from an oxygen source. Canad. med. Ass. J., 90, 1394.

Fearon, B. (1962). Acute laryngotracheobronchitis in infancy and childhood. Pediat. Clin. N. Amer., 9, 1095.

—, Smith, C., Delivoria-Papadopoulos, M., Levison, H., and Swyer, P. R. (1964). The idiopathic respiratory distress syndrome in the newborn. Ann. Otol. (St. Louis), 73, 1082.

Hanley, W. B., Braudo, M., and Swyer, P. R. (1963). Neonatal respiratory distress: experience at the Hospital for Sick Children, Toronto 1960-1961. Canad. med. Ass. J., 89, 375.

Heese, H. D., Wittmann, W., and Malan, A. F. (1963). The management of the respiratory distress syndrome of the newborn with positive-pressure respiration. S. Afr. med.J., 37, 123.

Natelson, S. (1951). Routine use of ultramicro methods in the clinical laboratory. Amer. J. clin. Path., 21, 1153.

Nelson, N. M., Prod'hom, L. S., Cherry, R. B., Lipsitz, P. J., and Smith, C. A. (1963). Pulmonary functions in the newborn infant: the alveolar-arterial oxygen gradient. J. appl. Physiol., $18,534$.

Peterson, H. G., Jr., and Pendleton, M. E. (1955). Contrasting roentgenographic pulmonary patterns of the hyaline membrane and fetal aspiration syndromes. Amer. J. Roentgenol., 74, 800.

Robertson, B., Tunell, R., and Rudhe, U. (1964). Late stages of pulmonary hyaline membranes of the newborn. Acta paediat. (Uppsala), 53, 433.

Severinghaus, J. W., and Bradley, A. F. (1958). Electrodes for blood $\mathrm{pO}_{2}$ and $\mathrm{pCO}_{2}$ determination. J. appl. Physiol., 13, 515. 
Singer, R. B., and Hastings, A. B. (1948). An improved clinical method for the estimation of disturbances of the acid-base balance of human blood. Medicine (Baltimore), 27, 223.

Stahlman, M., Young, Wm., and Payne, G. (1962). Studies of ventilatory aids in hyaline membrane disease. Program and abstracts. Soc. for Pediatric Research, 32nd Annual Meeting. p. 12. (Abstr. Amer. J. Dis. Child., 104, 526.)
Strang, L. B., and MacLeish, M. H. (1961). Ventilatory failure and right-to-left shunts in newborn infants with respiratory distress syndrome. Pediatrics, 28, 17.

Warley, M. A., and Gairdner, D. (1962). Respiratory distress syndrome of the newborn-principles in treatment. Arch. Dis. Childh., 37, 455. 